\title{
HEALTH VULNERABILITIES: THE DIAGNOSIS OF FRESHMEN FROM A PORTUGUESE UNIVERSITY
}

\author{
Felismina Mendes ${ }^{1}$, Manuel José Lopes ${ }^{2}$
}

\footnotetext{
${ }^{1} \mathrm{Ph} . \mathrm{D}$. in Sociology. Coordinating Professor at Universidade de Évora. Researcher at Instituto Superior de Ciências do Trabalho e Empresa - Instituto Universitário de Lisboa, Centro de Investigação e Estudos de Sociologia-Instituto Universitário de Lisboa. Lisbon, Portugal. E-mail: fm@uevora.pt

2 Ph.D. in Nursing. Coordinating Professor at Universidade de Évora. Researcher at Centro de Investigação em Ciências e Tecnologia da Saúde. Évora, Portugal. E-mail: mjl@uevora.pt
}

\begin{abstract}
The start of university is presented as a crucial stage in the life of the student. If, on the one hand, it is a period of increased autonomy and freedom, on the other, it is a period that also increases the sense of responsibility and self discipline. In this study, based on a quantitative approach, we identified the main risk situations experienced by freshmen at the University of Evora, by applying a questionnaire developed for this purpose and the Beck inventory. Key findings are highlighted, such as the consumption of harmful substances (tobacco, alcohol and illicit drugs), whose values exceed the average population. The consumption of alcoholic beverages begins early and is continuous and excessive. Also, the presence of symptoms compatible with dysphoria and depression is noted in about $9 \%$ of students. Self-medication practices were found in $58.7 \%$ of the freshmen. Our findings reveal the need for preventive intervention by health professionals, due to these young people's great exposure to health risks.
\end{abstract}

DESCRIPTORS: Nursing care. Health promotion. Student health services. Personal health services

\section{VULNERABILIDADES EM SAÚDE: O DIAGNÓSTICO DOS CALOIROS DE UMA UNIVERSIDADE PORTUGUESA}

RESUMO: O ingresso na universidade apresenta-se como uma fase crucial na vida do estudante, fase em que há aumento da autonomia e liberdade, do sentido de responsabilidade e a da autodisciplina, mas propicia mais acesso aos riscos à saúde. Como o objetivo de identificar as situações de risco experenciadas pelos caloiros de Universidade de Évora, desenvolveu-se um estudo quantitativo cujos dados foram coletados mediante a aplicação de um questionário e do inventário de Beck. Destaca-se o consumo de substâncias nocivas (tabaco, álcool e drogas ilícitas), cujos valores superam a média da população portuguesa e a presença de sintomatologia compatível com disforia e depressão em cerca de $9 \%$ dos estudantes. Verificou-se a prática da auto-medicação em $58,7 \%$ dos ingressantes. Os achados deste estudo revelam a necessidade de uma intervenção preventiva por parte dos profissionais de saúde devido a alta exposição aos riscos de saúde destes jovens.

DESCRITORES: Cuidados de enfermagem. Promoção da saúde. Serviços de saúde para estudantes. Assistência individualizada de saúde.

\section{VULNERABILIDADES EN SALUD: EL DIAGNÓSTICO DE ESTUDIANTES DE PRIMER AÑO DE UNA UNIVERSIDAD PORTUGUESA}

\begin{abstract}
RESUMEN: La concurrencia de transición se presenta como una etapa crucial en la vida del estudiante que entra en la universidad. $\mathrm{Si}$, por un lado, se trata de un período de mayor autonomía y libertad, por el otro, es un período que también aumenta el sentido de responsabilidad y autodisciplina. En este estudio, basado en un enfoque cuantitativo, se identificaron las situaciones de riesgo principales experimentados por estudiantes de primer año en la Universidad de Évora, mediante la aplicación de un cuestionario elaborado para tal efecto y el inventario de Beck. De relieve los principales hallazgos como el consumo de sustancias nocivas (tabaco, alcohol y drogas ilícitas), cuyos valores superan la media de la población. El consumo de bebidas alcohólicas comienza temprano y es un consumo continuo y excesivo. Tenga en cuenta también la presencia de síntomas compatibles con disforia y depresión en alrededor del 9\% de los estudiantes. También los valores obtenidos con la práctica de la automedicación muestra que si existe una situación por encima de los valores encontrados en otros estudios. Nuestros resultados revelan la necesidad de intervención preventiva de los profesionales de la salud.
\end{abstract}

DESCRIPTORES: Cuidados de enfermería. Promoción de la salud. Servicios de salud para estudiantes. Atención individual de salud. 


\section{INTRODUCTION}

The transition from secondary to higher education represents a crucial phase in students' lives. If, on the one hand, it is a period of increased autonomy and freedom, on the other, it also increases the sense of responsibility and self discipline. Students going through this transition will have to cope with a set of processes and contexts they are not familiar with and that range from the search for a room or house to administering money and a social life that is completely different from what they were accustomed to. The main difficulty, however, is the fact that they accomplish all of these tasks far from home and their context of origin in most situations, and sometimes with a lack of support to solve problems that may emerge. ${ }^{1}$

In this phase, the time of structured teaching, supported by manuals and closer contact with the teachers disappears and makes room for a complex and depersonalizing environment. In university, the institution's monitoring of and interest in the students is clearly more limited, so that the students' involvement in their education depends much more on themselves than on the university environment. The responsibility for learning, which used to be centered on the school, is now dislocated to the young people. They are expected to display autonomy in learning, in their administration of time and in the setting of targets and strategies for their academic success. ${ }^{2}$

Despite the increased expectations regarding the students' individual responsibility in their education and adherence to the course, it is verified that some characteristics of the university context, such as the opportunity for interaction with professors and the involvement in extracurricular activities enhance the students' integration with that environment. ${ }^{3}$ Thus, experiences during the freshman year in university are considered very important for the students' continuation in higher education and for their academic success. Moreover, students who get academic and socially integrated since the start of their courses seem to have more chances of intellectual and personal growth than those who face more difficulties in the transition to college. ${ }^{4}$

Nevertheless, the start of higher education is also a transition that entails potential repercussions for the psychological development of the freshmen. First, it often represents the first important attempt to implement a sense of autonomous identity. This attempt takes the form of choosing (or attempting to choose) a professional option, which is a typical developmental task in the transition from adolescence to adult life. Studies have revealed, however, that the option made is not always central in the constitution of the freshmen's identity. For some, the mere fact of starting higher education and identifying themselves as university students seems to stand out more than the course itself or the future profession it gives access to. ${ }^{5}$

The start of college also implies a range of transformations in the young students' networks of friends and social support. The college world, as opposed to the universe of secondary education, is less structured. Hence, adjusting to college also implies social integration with the people in this new context, participation in social activities and the development of satisfactory interpersonal relations. ${ }^{6}$ According to different authors, the quality of the students' parental relation during and even before starting higher education is a factor that also influences the adaptation to university. ${ }^{7}$ The perceived emotional support from the parents, reciprocity in the parent-children relations, the family dialogue about daily university life and parental support in specific issues related to the transition seem to contribute to the adaptation to the college context. For others, the young people who find themselves psychologically separated from their parents, but maintain positive feelings about this separation, tend to adapt better to university than those who feel more dependent on their parents in psychological terms. ${ }^{8}$ Some studies indicate that young people who developed a patterns of attachment/safe support tend to be less self critical, making them get more involved in social interactions and experience less solitude and depression in the freshman year.

The transitional concurrency (end of adolescence, start of adulthood, new contexts, requirements, friends and for many a probable departure from home and change of housing ${ }^{9}$ ) the young students experience when they start college can not only be a stressful experience for the young students, but also entail health vulnerabilities. In this phase, many new habits are acquired and reinforced, which can turn into health-related lifestyle models, which these young people can adopt and maintain sufficiently long to entail health problems. 
Knowledge acquisition and alimentary activities, physical exercise and preventive behaviors are consolidated during childhood and youth. Solid evidence exists that the individual lifestyle, defined as a set of beliefs, values and attitudes that reflects in daily habits, strongly influences health in general and determines the individual health status in the long term. ${ }^{10}$ Lifestyle turned into one of the most important health determinants for individuals, groups and communities. ${ }^{11}$ Despite all available information, however, behavioral studies reveal that college students increasingly adopt risk behaviors. Also, although the young students are aware that health is the foundation of quality of life, they demonstrate little concern with risk behaviors for health. ${ }^{12-13}$

Different studies highlight that the risk behaviors acquired in the college phase tend to perpetuate in adulthood and that the health attitudes established in youth can entail important impacts for the occurrence of future illnesses. ${ }^{10}$ In a study undertaken in 13 European countries (Belgium, England, France, Germany, Greece, Hungary, Iceland, Ireland, Italy, the Netherlands, Poland, Portugal and Spain), between 1990 and 2000, it was verified that, despite the knowledge about healthy habits, the students health-related lifestyles became less healthy due to the reduction in the level of physical exercise and the increased consumption of hardly nutritive foods. ${ }^{14}$

In this context, knowing the health-related lifestyles of college students is fundamental to enhance knowledge about their health habits and to permit the identification of the health risk behaviors profile so that, if necessary, universities can elaborate action plans to revert this situation, as certain risk behaviors can negatively influence the academic performance, compromising the quality of teaching and learning and thus representing an inappropriate public investment at the level of the University's social responsibility.

Thus, the objective in this research was to identify the risk situations for the health of freshmen who entered the University of Évora in 2009/2010.

\section{METHOD}

In this research, a quantitative and descriptive case study was chosen. The case study is a comprehensive characteristic that designates a wide range of studies that collect and register data about one or more particular cases with a view to the organization of a critical report or its analytic assessment, in order to make decisions or propose a transformative action.

The sample consisted of all students who entered the University of Évora in the academic year 2009/2010, totaling 1486. In total, 525 students answered the questionnaires, 472 of which were validated, corresponding to $31.8 \%$ of all freshmen.

The research subjects were intentionally contacted and received information about the research objectives. The confidentiality of the data was guaranteed and the students' informed consent was obtained.

The research was submitted to the Ethics Committee in the Area of Health and Wellbeing at the University of Évora in Portugal, under protocol 10037. All ethical premises were complied with, in accordance with the Helsinki Declaration of Ethics in research involving human beings.

Two data collection instruments were used. The first was a questionnaire that mainly included closed questions, with answers on a Likert scale, and structured as follows: 1) Sociodemographic variables: questions related to city of origin, nationality, sex, age, existence of siblings, profession and education level of parents, course, whether the course was the first career option and whom the student lives with; 2) Daily activities: The dietary habits, physical exercise practice and locomotion (time to reach the University and transportation means used) were assessed; and 3) Harmful consumption: questions related to the history of harmful consumption (alcohol, tobacco and illegal drugs) and consumption of medicines without a medical prescription.

In addition, the Beck Depression Inventory $\mathrm{II}^{15}$ was applied to assess the presence of depression symptoms in the previous two weeks. Only 372 out of all (472) respondents answered all items in the Inventory. Hence, only these 372 were analyzed, as this instrument can only be analyzed when all items have been answered.

The data were statistically processed, using SPSS $16.0^{\circledR}$. The results were organized in the form of tables and graphs.

\section{RESULTS}

Students from all courses offered at the University were investigated. In figure 1, the percentage results of the answers obtained in each course are presented. 


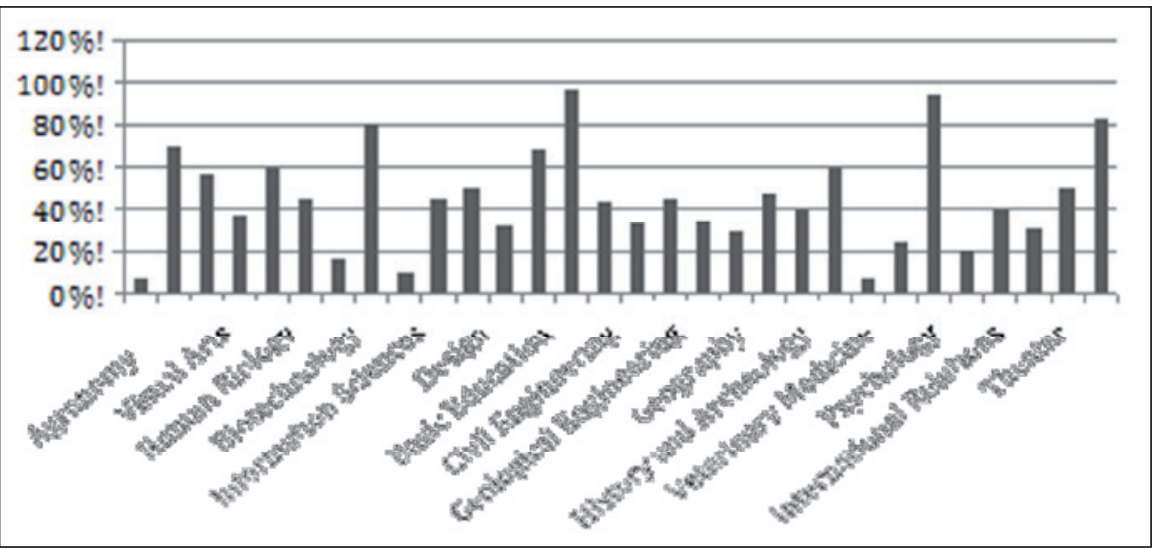

Figure 1 - Percentage distribution of students in each course that participated in the study. Évora, 2009

The analysis of figure 1 reveals that the respondents' distribution was neither homogeneous nor proportional across all courses.

Most participants were women (66.9\%), the mean age was 19.6 years and $95.4 \%$ of the students were single.

Table 1 - Education level of parents. Évora, 2009

\begin{tabular}{lcc}
\hline $\begin{array}{l}\text { Parents } \\
\text { education level }\end{array}$ & $\begin{array}{c}\text { Father } \\
\%\end{array}$ & $\begin{array}{c}\text { Mother } \\
\%\end{array}$ \\
\hline Up to ninth year of education & 57.9 & 52.7 \\
12 years of education & 21.4 & 24.3 \\
Professional Course & 8.1 & 7.3 \\
Higher Education Course (un- & 11.6 & 15.1 \\
dergraduate) & 1.0 & 0.6 \\
Did not answer & $\mathbf{1 0 0}$ & $\mathbf{1 0 0}$ \\
\hline
\end{tabular}

As regards the parents' academic level, most parents hold a degree that is similar to the country's average (Portugal), in the lower as well as the higher education degrees.

The investigated students share a rented house with peers $(41.1 \%)$ and live with their parents $(23.8 \%)$ or in student homes $(15.5 \%)$. Concerning the time spent to reach the University, $46.2 \%$ take ten minutes at most and 33.2\% take between 11 and 20 minutes. Most students (67.2\%) go to the University on foot. It is highlighted that Évora is a small city (about 56 thousand inhabitants) and that most University buildings are located in the city center, facilitating the students' access and transportation.

Table 2 - Distribution of participants according to meals and frequency. Évora, 2009

\begin{tabular}{|c|c|c|c|c|c|c|}
\hline \multirow{2}{*}{$\begin{array}{c}\text { Refeições por } \\
\text { sexo }\end{array}$} & \multicolumn{2}{|c|}{$\underset{\%}{\text { P. Alm. }}$} & \multicolumn{2}{|c|}{$\underset{\% / 6}{A}$ Im. } & \multicolumn{2}{|c|}{$\begin{array}{c}\text { Jantar } \\
\%\end{array}$} \\
\hline & $\mathbf{M}$ & $F$ & $\mathbf{M}$ & $F$ & $\mathbf{M}$ & $F$ \\
\hline $\begin{array}{l}\text { Toma sempre } \\
\text { As vezes } \\
\text { Dias alternados } \\
\text { Rasamente } \\
\text { Total }\end{array}$ & $\begin{array}{r}78,8 \\
3.9 \\
11,8 \\
10,5 \\
100\end{array}$ & $\begin{array}{r}82,3 \\
1,3 \\
13,1 \\
3,3 \\
100\end{array}$ & $\begin{array}{l}87.5 \\
5.9 \\
3.9 \\
2,7 \\
100\end{array}$ & $\begin{array}{l}92,5 \\
5,2 \\
1.4 \\
0,9 \\
100\end{array}$ & $\begin{array}{l}90,8 \\
3.9 \\
3.9 \\
1,4 \\
100\end{array}$ & $\begin{array}{l}89.2 \\
6,8 \\
2,6 \\
1,6 \\
100\end{array}$ \\
\hline
\end{tabular}

In the data collected on the dietary habits, it is highlighted that $10.5 \%$ of the male students rarely have breakfast.
Also regarding the dietary habits, $17.8 \%$ of the students affirm eating sweets daily and $40.0 \%$ affirm eating fruit only sometimes or rarely. The same trend is found for vegetable consumption, 
which $42.4 \%$ do rarely or only sometimes. What the consumption of soft drinks is concerned, $42.7 \%$ drink these beverages daily or at least on alternate days. Coffee is consumed daily by $35.1 \%$ of the students. Milk is part of the dietary habits of $64.7 \%$ of these young people.

Table 3 - Frequency of physical exercise according to sex. Évora, 2009

\begin{tabular}{lcc}
\hline \multicolumn{1}{c}{ Prática de atividade fisica } & $\begin{array}{c}\text { Masculino } \\
\%\end{array}$ & $\begin{array}{c}\text { Feminino } \\
\%\end{array}$ \\
\hline Diariamente & 27,6 & 12,1 \\
Em dias altemados & 15,1 & 7,2 \\
As vezes & 38,8 & 50,3 \\
Raramente & 15,1 & 22,5 \\
Nunca praticam & 5,2 & 7,8 \\
Total & 100 & 100 \\
\hline
\end{tabular}

The collected data reveal that physical exercise is not part of the freshmen's daily habits, mainly among girls. Those that do practice daily or on alternate days prefer jogging, soccer and walking.

Table 4 - Consumption habits of legal and illegal substances according to sex. Évora, 2009

\begin{tabular}{|c|c|c|c|c|c|c|c|c|}
\hline \multirow[t]{2}{*}{$\begin{array}{l}\text { Consumo de } \\
\text { Substância }\end{array}$} & \multicolumn{2}{|c|}{$\underset{\% / 6}{A}$} & \multicolumn{2}{|c|}{$\begin{array}{c}\text { Tabaco } \\
\%\end{array}$} & \multicolumn{2}{|c|}{$\underset{\%}{\text { Drogas ificitas }}$} & \multicolumn{2}{|c|}{$\begin{array}{c}\text { Consumo de } \\
\text { medicamentos } \\
\text { (sem prescrição } \\
\text { médica) \% }\end{array}$} \\
\hline & $M$ & $\bar{F}$ & $\bar{M}$ & $F$ & $M$ & $F$ & $\mathbf{M}$ & $F$ \\
\hline Já corsumiu & 97.6 & 97.1 & 74,5 & 64,3 & 45.9 & 31,7 & 48,2 & 63.5 \\
\hline $\begin{array}{l}\text { Nunca } \\
\text { consumiu }\end{array}$ & 2,5 & 29 & 25,5 & 35,7 & 54,1 & 68,3 & 51,8 & 38,5 \\
\hline Total & 100 & 100 & 100 & 100 & 100 & 100 & 100 & 100 \\
\hline
\end{tabular}

As regards the consumption habits of legal and illegal drugs, the high percentage of freshmen who have already consumed alcohol is highlighted. The consumption levels of medicines without medical prescription are also noteworthy.

The collected data reveal that $50.6 \%$ of the freshmen answered that they started using alcohol before the age of 14 years, that $9.4 \%$ drink daily and that $11.2 \%$ indicate drinking on alternate days.

Concerning tobacco consumption among the students, $26.2 \%$ affirm daily consumption and most students $(68.9 \%)$ consumed tobacco for the first time between the ages of 14 and 17 years.

In addition, students who have already experienced illegal drugs did so between 16 and 18 years of age. It is emphasized that $2 \%$ affirm daily consumption.

The collected data also reveal that, among the students who practice self medication, $38.8 \%$ indicate "pains" and 26.6\% "illness" as a motive for these practices. No questions were asked about what medicines they consume most.

Table 5 - Sample distribution according to sex and symptoms of dysphoria and depression. Évora, 2009

\begin{tabular}{ccccccccc}
\hline \multirow{2}{*}{ Gender } & \multicolumn{2}{c}{ Normal } & \multicolumn{2}{c}{ Dysphoria } & \multicolumn{2}{c}{ Depression } & \multicolumn{2}{c}{ Total } \\
\cline { 2 - 9 } & $\mathbf{N}$ & $\mathbf{\%}$ & $\mathbf{N}$ & $\mathbf{\%}$ & $\mathbf{N}$ & $\mathbf{\%}$ & $\mathbf{N}$ & $\%$ \\
\hline Male & 94 & 26.5 & 11 & 3.1 & 8 & 2.3 & 113 & 31.9 \\
Female & 198 & 55.8 & 21 & 5.9 & 23 & 6.5 & 242 & 68.1 \\
\hline Total & $\mathbf{2 9 2}$ & $\mathbf{8 2 . 3}$ & $\mathbf{3 2}$ & $\mathbf{9 . 0}$ & $\mathbf{3 1}$ & $\mathbf{8 . 8}$ & $\mathbf{3 3 5}$ & $\mathbf{1 0 0}$ \\
\hline
\end{tabular}


The application of the Beck Inventory II revealed the presence of depression symptoms among the students in the previous two weeks, as observed in table 5 . As verified, $8.8 \%$ of the students present depressive symptoms, with girls $(6.5 \%)$ predominating over boys $(2.3 \%)$.

Pearson's correlation analysis revealed a significant but weak correlation between the students' sex and physical exercise practice.

\section{DISCUSSION}

The dietary habits cannot be dissociated from health and, despite being confronted daily with countless messages from official entities about the importance of the diet to maintain health, particularly alerting about the excessive consumption of high-calorie foods with low nutritional contents, various studies among college students in different countries reveal that their dietary behaviors are inappropriate. Three indicators tend to be used to analyze individuals' dietary habits, focused on the low consumption of fruit and vegetables, the excessive consumption of sweets and the low daily meal frequency. These indicators are a posteriori associated with obesity, overweight and chronic and degenerative diseases (stroke, hypertension, cerebrovascular accident, among others). ${ }^{12}$

Often associated with a change of environment, changes in dietary habits occur that can entail important consequences for health in the future. The pattern found, however, seems to be in accordance with the prevailing patterns in today's young adults, with constant consumption of sweets and soft drinks, as opposed to fruit and vegetables. ${ }^{17}$ According to the referred authors, college students, namely those living alone or in student homes, attribute this fact to the lack of time to eat correctly and the dedication college life demands. Finally, it should be highlighted that recent studies in neurosciences have demonstrated the associated between reduced brain performance and low dietary quality and daily frequency.

Sedentariness seems to be common practice among the students, particularly among girls. It is emphasized, however, as mentioned earlier, that most students go to the University on foot.

Consensual evidences exist that associate satisfactory health levels with regular physical exercise as a form of leisure and there seems to exist an agreement in the scientific community that this practice stands out as one of the most important factors for a healthy lifestyle. ${ }^{10}$ Like with the dietary habits, however, most participants are unable or do not make efforts to achieve the minimum recommendation of 30 minutes of moderate physical exercise per day at least five times per week. ${ }^{18}$ The same author affirms that, despite increasing opportunities to perform physical exercise in recent years, the individuals hardly use them.

Studies among college students have revealed concurrent results, highlighting young students' weak adherence to physical exercise, independently of their knowledge about the importance and need. ${ }^{19}$ The literature also reveals that the participation in physical exercise drops with growth, mainly from youth to young adulthood, due to the overburden of (class and/or work) hours and, among the university students, due to the need to use the free time for studying and other academic activities. The collected data revealed a positive correlation between sex and physical exercise, showing greater sedentariness among female students.

Concerning the consumption of alcohol, the data found are superior to the findings for the Portuguese population. In addition, $79 \%$ of the students affirmed that had already gotten drunk, $29 \%$ "in the last 30 days". Although the data were collected during the full period of initiation, once again the obtained rates exceed those of the Portuguese population, with rates between five and $14 \%$ for getting drunk "in the last 30 days" ${ }^{20}$ The high percentage of students saying they have already consumed alcohol and who consume it daily or on alternate days is highlighted (20.6\%). The data related to those who have already gotten or get drunk are a source of concern. The alcohol-related risk situations for these students' health and functioning reveal the participants' vulnerability. ${ }^{21}$

Tobacco consumption rates are superior to the values of the Portuguese population which, in 2007, remained below 19\%. In comparison with the mean rate for the European population, the percentage of students who smoke daily is slightly higher. In European countries, the percentage of students who consume tobacco regularly corresponds to $24 \%$. According to data for 2007, tobacco consumption in Portugal and other European countries in the last 30 days corresponds to 19 and $29 \%$, respectively..$^{20}$ In fact, the Portuguese emerge with one of the lowest smoking prevalence rates among the European countries, which is not the case for the freshman group analyzed. ${ }^{22}$ 
Illegal drugs also reveal much higher consumption rates when compared to the interval $6-15 \%$ in the Portuguese population who admitted the consumption of an illegal substance at least once, and also higher than the rates in the study from 2003, which indicated levels of $30.2 \%$ among Portuguese young adults aged 18 years. ${ }^{20}$

The data presented with regard to harmful substance consumption not only reveal once again the vulnerability and risk situations these young people are exposed to, but also reinforce the need for prevention and the elaboration of specific policies aimed at college students, so as to enable them to make their choices. ${ }^{23}$

The trend towards self-medication was also present in a study undertaken in 2008, involving Portuguese University students, which reveals that $52.4 \%$ self-medicate, ${ }^{23}$ similar to the present findings.

According to different studies, higher instruction levels seem to enhance the confidence in self-medication practices, which also serves as the main reason for the high levels of this practice among health students. ${ }^{24}$

The analysis of table 5 reveals that the mean rate of depressive symptoms among women is higher than among men, but without a statistically significant difference. It should also be underlined that these findings are similar to other studies involving Portuguese university students. ${ }^{25}$ In addition, similarities are found when comparing these findings with different studies among university students. ${ }^{16}$ Nevertheless, higher levels were found in a Brazilian sample used to validate the instrument. ${ }^{26}$ The analysis of the same table also shows that most students do not display any depressive symptoms whatsoever. Nevertheless, $9.1 \%$ present symptoms compatible with some degree of dysphoria, that is, sudden and transitory mood changes with feelings of sadness, anguish, crying, self-depreciation and failure. More relevant, however, is that $8.8 \%$ of the student present symptoms compatible with depression.

When comparing these results to the findings of other authors (dysphoria 6.1\% and depression $3.5 \%)^{16}$, the values were higher. Nevertheless, they are similar to the findings in a study developed in a sample of 370 pre-college students.

These values may be associated with the change and adaptation process these students are experiencing and which often take the form of more emotional difficulties, linked to difficulties to live alone or to adapt to the new social life the university imposes, in which the loss of privileged references (parents or other close relatives) gains more impacting dimensions and simultaneously illustrates the importance of family support for the adaptation of freshmen to the university context. ${ }^{7-8}$

\section{FINAL CONSIDERATIONS}

Based on the data, potential risk situations could be identified which result in the presence of inappropriate dietary behaviors and nonadherence to physical exercise. The combination of these two situations can lead to an association with future impacts, not only in terms of health, but also at the level of academic performance.

Another risk situation the investigated students experience is the consumption of harmful substances (tobacco, alcohol and illegal drugs), with rates superior to the average levels in the Portuguese population. In addition, they reveal an early start of alcohol consumption and a continuing and excessive consumption of alcohol and tobacco.

The self-medication levels also exceed the values found in other studies, showing yet another risk situation that demands intervention in this population, namely through the prohibition of medication propaganda inside the University and concerted actions on the dangers associated with the consumption of medicines without medical prescriptions.

As regards the data collected using the Beck Inventory II, the global average was similar to other Portuguese samples, without a significant difference in function of gender and a set of students with symptoms of dysphoria and/or depression.

The results evidence the importance of and need for prevention involving these students, including tailor-made actions focused on each health risk situation under analysis. Without preventive habits, the risks and consequent future impacts on these young people's health cannot be reduced. In fact, the college context plays an important role in the adaptation process to university, namely if this process implies situations that put the students' health at risk or that interfere in their daily functioning. Therefore, the creation of a health support service for freshmen is proposed, with constant preventive intervention and health promotion by health professionals. In addition, anyone interested in this problem should use established data 
collection instruments, so as to appoint common issues for the sake of comparability and professional intervention involving these students.

\section{REFERENCES}

1. Andrade AM, Teixeira MA. Adaptação à universidade de estudantes internacionais: um estudo com alunos de um programa de convénio. Rev Bras Orientac Prof. 2009 Jun; 10(1):33-4.

2. Soares AP, Almeida L, Diniz A, Guisande MA. Modelo Multidimensional de ajustamento de jovens ao contexto universitário (MMAU): estudo com estudantes de ciências e tecnologias versus ciências sociais e humanas. An Psicol. 2006 Jan; 1(24):15-27.

3. Fior CA, Mercuri E. Formação universitária: o impacto das atividades não obrigatórias. In Mercuri E, Polydoro SAJ, organizadores. Estudante universitário: características e experiências de formação. Taubaté (SP): Cabral; 2003.

4. Reason RD, Terenzini PT, Domingo RJ. First things first: feveloping academic competence in the first year of college. Res High Educ. 2006 Mar; 47:149-75.

5. Lassance MCP, Gocks A. A formação da identidade profissional em universitários: a questão da prática. Anais do II Simpósio Brasileiro de Orientação Vocacional e Ocupacional. 1995; São Paulo (SP): ABOP:65-70.

6. Diniz AM, Almeida LS. Adaptação à universidade em estudantes de primeiro ano: Estudo diacrónico da interacção entre o relacionamento com pares, o bem-estar pessoal e o equilíbrio emocional. Anal Psicol. 2006 Jan; 1(24): 29-38.

7. Mounts NS, Valentiner DP, Anderson KL, Boswell MK. Shyness, sociability, and parental support for the college transition: relation to adolescents' adjustment. J Youth Adol. 2006 Fev; 35(1):71-80.

8. Wiseman H, Mayseless $\mathrm{O}$, Sharabany R. Why they are lonely? Perceived quality of early relationships with parents, attachment, personality predispositions an loneliness in first-year university students. Personality and individual differences. 2006 Jan; 40:237-48.

9. Meleis AI. Transitions Theory: middle-range and situation-specific theories in nursing research and practice. New York (US): Springer Pub; 2010.

10. Nahas MV. Atividade física, Saúde e Qualidade de Vida. $4^{\mathrm{a}}$ ed. Londrina (PR): Midiograf; 2006.

11. Chór D. Saúde pública e mudanças de comportamento: uma questão contemporânea. Cad Saúde Pública. 1999 Abr-Jun; 15(2):423-5.

12. Franca C, Colares V. Estudo comparativo de condutas de saúde entre universitários no início e no final do curso. Rev Saúde Pública. 2008 Jun; 42(3):420-7.
13. Sánchez-Alemán MA, Conde-Glez CJ, Uribe-Salas F. Core group approach to identify college students at risk for sexually transmitted infections. Rev Saúde Pública. 2008 Jun; 42(3):428-36.

14. Steptoe A, Wardle J, Cui W, Bellisle F, Zotti AM, Baranyai R. Trends in smoking, diet, physical exercise, and attitudes toward health in European university students from 13 countries, 1990-2000. Prev Med. 2002 Aug; 35(2):97-104.

15. Beck AT, Steer RA. Beck depression inventory II: manual. San Antonio (US): The psychological corporation; 1987.

16. Gorenstein C, Andrade LH, Silveira G. Inventário de depressão de Beck: propriedades psicométricas da versão em português. Rev Psiquiatr Clín. 1998 Set-Out;25(5):245-50.

17. Coelho CWE, Santos JFS. Perfil do estilo de vida relacionado à saúde dos calouros de um centro de ciências tecnológicas. Revista Digital [online]. 2006 [acesso 2010 Mai 20];11(97). Disponivel em: http:/ / www.efdeportes.com/efd97/saude.htm

18. Waxman A. World Health Assembly. WHO global strategy on diet, physical activity and health. Food Nutr Bull. 2004 Sep; 25(3):292-302

19. Soares RDOP, Campos LF. Estilo de vida dos estudantes de enfermagem de uma universidade do interior de Minas Gerais. Cogitare Enferm. 2008 Abr-Jun; 13(2):227-34.

20. ESPAD, Ministério da Saúde - Serviços Centrais. Consumo de substâncias entre os alunos de 35 países europeus. Relatório ESPAD. 2007. p. 70.

21. Pillon SC, O'Brien B, Chavez KAP. A relação entre o uso de drogas e comportamentos de risco entre universitários brasileiros. Rev Latino-Am Enferm. 2005 Nov-Dec; 13(2):1169-76.

22. Machado A, Nicolau R, Dias CM. Consumo de tabaco na população portuguesa retratado pelo Inquérito Nacional de Saúde (2005/2006). Rev Port Pneumol. [online]. 2009 Nov-Dec [acesso 2010 Mai 20]; 15(6):1005-27. Disponível em: http:// www.elsevier.pt/pt/revistas/revista-portuguesapneumologia-320

23. Renovato RD, Bagnato MHS. Práticas educativas em saúde e a constituição de sujeitos ativos. Texto Contexto Enferm [online]. 2010 Jul-Set [acesso 2010 Mai 20]; 19(3):554-62. Disponível em: http:/ / www. scielo.br/pdf/tce/v19n3/a18v19n3.pdf

24. Ribeiro MI, Oliveira A, Silva H. Prevalência da automedicação na população estudantil do Instituto Politécnico de Bragança. Rev Port Sau Pub. 2010 Jan-Jun; 28(1):41-8.

25. Alguns dados sobre a prevalência de sintomatologia depressiva na população universitária portuguesa. Actas da X Conferência Internacional de Avaliação Psicológica, 15 a 18 Setembro de 2004. Braga (PT): Psiquilibrios Edições; 2004. 
26. Gorenstein C, Andrade L, Hélio A, Filho AV, Tung TC, Artes R. Psychometric properties of the Portuguese version of Beck depression inventory on Brazilian college students. J Clin Psychol. 1999 Mai; 55(5):553-62. 